\title{
Management Reforms in Activation Programmes and Public Employment Services: The Turkish Case
}

\author{
Aslı GÜLEÇ TAŞDEMIR ${ }^{1}$ \\ ORCID: 0000-0002-5750-1661 \\ DOI: $10.54752 /$ ct. 1060800
}

\begin{abstract}
There are many studies on the ways in which activation paradigm has been integrated into the reform of welfare states. Activation paradigm and related policies serve to activate citizens to take more responsibility for their own welfare through paid employment. Active labour market policies (ALMPs) have constituted one of the important policy fields in which active welfare understanding have been materialised and thus become a significant instrument of activation. These programs and relevant measures constitute formal policy reforms. There is also a rising literature on procedural policy reforms in the field of activation, which is about the ways that ALMPs are managed, that is, the governance of activation. Recent procedural reforms include measures shaped by the New Public Management thinking such as performance management or management by objectives, and the process of marketization through quasi markets. The debates on the governance of activation show the ways in which management reforms shape the content of activation reforms. This study attempts to evaluate those debates on procedural reforms in ALMPs through review of the relevant literature and based on the Turkish case. Turkey is a late comer in implementation of activation programmes but in the last two decades policy reforms both in ALMPs and in the ways formal policy reforms are governed and implemented have accelerated.
\end{abstract}

Key words: Activation, active labour market policies, management reforms, public employment services, Turkey.

Aktivasyon Programlarında Yönetim Reformları ve Kamu İstihdam Hizmetleri: Türkiye Örneği

Öz: Etkinleştirme (aktivasyon) paradigmasının refah devletlerinin yeniden yapılandırılmasına etkisini konu alan birçok çalışma bulunmaktadır. Aktivasyon anlayışını yansıtan politikalar, yurttaşların ücretli çalışma yoluyla kendi refahları için daha fazla sorumluluk

${ }^{1}$ Dr. Öğrt.Üyesi, Kocaeli Üniversitesi, Çalışma Ekonomisi ve Endüstri İlişkileri Bölümü, Makale Geliş Tarihi: 02.07.2021 - Makale Kabul Tarihi: 11.12.2021 
almaları yönünde etkinleştirilmelerine hizmet etmektedir. Aktif işgücü politikaları ise aktif refah anlayışının somutlaştı̆ı önlemler olarak, aktivasyon anlayışının en önemli araçlarından biri olarak değerlendirilmektedir. Söz konusu politikalar formal politika reformlarına karşılık gelmektedir. İlgili yazında aktivasyon politikaları alanında prosedürel reformları konu edinen çalışmalar da önem kazanmaktadır. Bu yazın, aktif işgücü politikalarının yönetimi ya da aktivasyonun yönetişimi (management of activation) olarak tartısılmaktadır. Prosedürel reformlar özellikle Yeni Kamu Yönetimi anlayışı altında şekillenen amaçlar bağlamında yönetim ve yarı piyasalar yoluyla piyasalaşma gibi süreçleri içermektedir. Aktivasyonun yönetişimi tartısmaları yönetim reformlarının formal reformların içeriğini de etkilediğini de göstermektedir. Bu çalşsma, aktif işgücü politikalarını ilgili yazındaki prosedürel reformların değerlendirilmesi ve Türkiye'de kamu istihdam hizmetlerinin sunumunda hayata geçirilen reformlar bağlamında ele almayı amaçlamaktadır. Türkiye, aktivasyon programlarınin uygulanması ve kamu istihdam hizmetlerinin reformu açısından geç kalan bir ülke olarak değerlendirilebilir.

Anahtar kelimeler: Aktivasyon, aktif işgücü reformları, yönetim reformları, kamu istihdam hizmetleri, Türkiye.

\section{Introduction}

The process of activating welfares systems/states has been a decisive trend in transforming the relation between the spheres of work and welfare (Van Berkel, 2012a; Van Berkel, 2012b). Active welfare understanding as part of modernization of welfare states has been considered to redefine the relations between both citizens and the welfare state, and the state and markets. The rise of social investment approach, the persistent use of workfare strategies, significance attached to active labour market policies (ALMPs) and paid work as the main path for social integration and social inclusion within activation strategies of social investment are specific examples of active welfare understanding. Activation strategies which have been implemented through active labour market policies have been developed to increase the employability of inactive population such as long-term unemployed or social assistance recipients have contributed to the consolidation of active welfare notion (Newman, 2002: 365).

The importance attached to work and active welfare notion corresponds to an ideological process that has changed the ways we think about welfare state with its redistributive functions in income maintenance (thought as passive welfare) and the non-commercial nature of welfare provision. Peck (2002: 331) analyses the political economy of welfare reform as "referring to the transnational shift in social and labour market policy toward activation, employability-oriented programming 
and residualized or market-tested welfare provision". In analysing such ideological and political shift notions of enabling state, activating state, workfare state has been used. Even though the enabling role of the state is associated with the social investment approach and workfare state comes to define neo-liberal, paternalist nature of activation policies both concepts underline the ways that the state takes a considerable role in recommodifying labour (Knotz, 2018; Deeming and Smyth, 2015; Whitworth and Carter, 2014; Dostal, 2008; Vis, 2007; Grover and Stewart, 1999). Deeming and Smyth (2015) states that the emphasis on understanding of social policy as a productive, economic investment within which paid work is seen as the primary path for social inclusion within an inclusive growth strategy (Jenson, 2015; Deeming and Smyth, 2015: 303).

There are two facets of what is called activation paradigm (Bonvin, 2008: 367). The first one is about the implementation of distinct forms of ALMPs (human capital development and work-first programmes) to ensure labour market integration, and the second one is related to the development of organisational and procedural reforms through which activation programmes are managed (Bonvin, 2008). Van Berkel (2009) also explains the attempts to make "welfare states more active" on the basis of two forms of reform strategies including formal policy reforms that influence the content of welfare programmes, and those operational policy reforms that "aim at restructuring service provision models, that is the design of the organisational arena through which policy programmes administered and delivered" (Van Berkel, 2009: 17).

There is a developed literature explaining the nature and implications of activation programmes both at theoretical level and in different policy contexts (Heidenreich and Graziano, 2015; Ludwig-Mayerhofer et al., 2014). As part of the process of shift from passive social policy understanding to active one, activation paradigm sets new rules requiring unemployed people, jobseekers and social assistance recipients to take more responsibility for their own welfare in order to justify welfare support and decrease welfare dependency through self-reliance (Ludwig-Mayerhofer et al., 2014; Newman, 2007). What is called "activation of jobseekers" (Considine et al., 2018: 1187) is evaluated within the process of neoliberalization referring to "reform processes that respond to common pressures to improve place-based competitiveness, but which are implemented in localised, contingent and path-dependent ways" (Nunn and Morgan, 2018: 1187). Paternalist and coercive nature of some forms of activation strategies such as workfare programmes are also known (Nunn, 2019; Penz et al., 2017; Ludwig-Mayerhofer et al., 2014; Nunn, 2018: 168). ALMPs have been introduced to sustain and improve the skill development of workforce (Dostal, 2008) but it is also noted how ALMPs are used to overcome poverty traps emerged due to generous and comprehensive welfare programmes and lack of work incentives.

The other related facet of activation policies is about the services delivery programmes, that is, the ways that service programmes are administered and 
managed (Newman, 2007). Indeed, formal policy reforms necessitates what is called a new governance structure underpinning effective implementation, and new organizational and institutional structures have significant consequences for the content of social policies. In other words, social policies are restructured through viable modes of governance to encourage responsible behaviour among welfare recipients, local level institutions and the welfare state (Heidenreich and Graziaono, 2014; Bonvin, 2008: 365; Newman, 2007). This is also related to the fact that social policy measures practically become meaningful through implementation, that is, the ways that such measures are practiced (Brodkin, 2006). As Van Berkel (2009: 18) states "these governance reforms influence the agents involved in service provision and the structure of their relationships as well as the ways in which old agencies are governed and managed". In the case of activation, the principal agencies are those Public Employment Service Agencies (PES) at national and local level. PES is the principal institution accountable for initiating labour market polices in many countries. Recently, in relation to ALMPs, PES have assumed additional roles in activation through counselling, placement, training or monitoring services and reducing benefit caseload (Grubb, 2004: 354-355).

This study concerns with a general evaluation of procedural reforms introduced in PES and aims at reviewing the principal implications of management reform measures through review of existing debates based on the evaluation of public employment reforms in Turkey in the last two decades. Turkey can be considered as laggard in initiating comprehensive activation programmes and restructuring of public employment services. Explaining the nature of ALMPs and related procedural reforms in Turkey will enhance our understanding on the main implications of "activation turn" in a policy context which can be seen as a late comer. The activities and the role of private employment agencies (PEAs) will not be elaborated within this paper.

This study will cover the main theoretical and policy debates on PES reforms by reviewing the relevant literature. With respect to the Turkish case, this study will also rely on the official documents, reports issued by the public employment agency.

In order to discuss how procedural policy reforms affect public employment services, this study first gives attention to both formal and management reforms strategies in activation programmes. Secondly, it explains the process of marketization in public employment services. Third, the paper explains the performance management practices in the same policy field and this section is followed by debates on individualization and decentralization in PES reforms. The last part of the study will evaluate the key facets of procedural policy reforms in public employment services in Turkey. 


\section{Activation Policies and Public Employment Services}

PES play considerable role in implementing and delivery of programmes with respect to employment policies and labour markets (Nunn, 2018: 167). Some of the main tasks include matching labour supply and demand, to provide support for jobseeker through offering professional information, counselling and guidance, administration of adjustment programmes, skill development or work experience programmes (OECD, 2005; Kalvane, 2015; Soantken and Weishaupt, 2015; Terziev, 2000). The ways that these services are delivered have significant implications for government policies in relation to labour markets. Hence, formal policy reforms might generate a need for administrative and management reforms in the operation of institutions delivering services (Van Berkel, 2009). These reforms can be analysed within a broader framework of public administration reforms shaped by partly the discourse of the lack of effectiveness and efficiency of old, traditional public sector and the policy influence of New Public Management (NPM) paradigm (Van Berkel, 2009: 19). Such measures have also been advanced to respond "the complexity of society" through new means of administration (Klijn, 2012). As activation strategies take the paid work as the most viable route to welfare and social integration the role of PES has shifted to increase the employability of jobseekers through activating them. Decreasing the number of welfare recipients, supporting employment, and overcoming welfare dependency are amongst other general goals of PES (Nunn, 2018: 167; Nunn, 2010). This is described as the second form of "double activation" notion involving systemic changes in the ways that policies are implemented (Considine et al., 2018: 1187).

It has been management measures under the NPM approach and governance reforms that have shaped the nature of reforms in both PES and associated benefit agencies. Policy measures associated with the NPM ideas generally involve the establishment of quasi-markets, the use of contracts and tendering mechanisms in service delivery and the launch of performance management techniques. Individualization, privatization, and marketization are the principal results of these measures. The processes of decentralization and recentralization in public employment services should also be noted (Hill, 2013; Weishaupt, 2010; Newman, 2007; Bonvin and Moachon, 2007).

In relation to both public sector reform and employment policies two related theoretical debates are relevant, that is, those debate on different modes of governance in employment policies and the influence of the NPM thinking (Considine and Lewis, 2013). With respect to old traditional public sector structures these two debates share a similar discursive framework underlining the need to restructure public sector institutions which are considered "too big, too rigid, too standardized and too insensitive to individual identities" (Considine and Lewis, 2003: 131). Proceduralism and too much supervision has also been criticised. By tracing the reform process to the second half of the 1970s Considine 
and Lewis (2003) specify four ideal types of governance including procedural governance, corporate governance, market governance and network governance. Procedural governance defining the old bureaucratic structure is characterised by specific rules, existence of strong supervision and universal delivery of services. Corporate governance has developed on the basis of criticism raised against procedural governance and promoted a management structure in public sector just like corporations are managed. Target setting, performance measures, setting plans as goal oriented are known features. Market governance has become influential with the growing use of quasi-markets as an organizing principle in coordination and delivery of public services through competitive tendering and contracting out. Considine and Lewis (2003: 132-133) state the ways in which market governance are might bring "greater flexibility, reduced planning and less regulation". They also note how market governance has been extended to replace old form of public service provision with multiple private and public providers and purchasers for further efficiency. Network governance, on the other hand, necessitates a reliance on partnership within which providers and clients are party to network organization called "joined-up" government characterised by joint action and flexibility (Considine and Lewis, 2003: 133-134).

With respect to the influence of the NPM paradigm which is shaped by public choice theory the reforms in public sector have been framed within the discourse of efficiency and effectiveness of business-like public administration (Nguyan and O'Sullivan, 2018; Yeh and Lin, 2018; Penz et al., 2017; Considine et al., 2014; Sol, 2010; Bonvin, 2008; Newman, 2007; Pollitt, 2002). The main arguments raised by neoliberals against the Keynesian welfare state was influential since monopolistic welfare provision with centralised structures and the problem of bureaucratic over-supply are assumed to limit consumer choice and increase the financial burden of public sector. A new public management structure run like business sector then would lead to more responsive, improved, accountable, consumer oriented and innovative service provision structure (Considine et al., 2018: 1188; Considine et. al, 2014: 470-471).

Looking at the major facets of NPM thinking, Ehrler (2012: 328) and Pollitt (2002: 474) state the use of performance management system with a system of management by objectives, existence of contracts, the role of discretion at the level of implementation, increasing use of performance management, markets and market like mechanisms in the service provision, closer relationships between public-private partnerships and a shift in the normative values from egalitarianism and universalism towards efficiency and individualism as the main principles. Given this, the NPM approach may cover policy instruments such as contracts, quasi markets, vouchers, or performance band pay serving to both to blurring the frontiers of public and private sectors in the service delivery and divide the service provision and funding roles of governments (Sol, 2010: 345; Pollitti, 2002). 
Although the NPM practices are widely used in employment services especially in Anglo-Saxon countries such as the US, the UK and Australia in other countries including the Netherlands, Denmark, Germany and Sweden specific forms of such practices have been introduced. For instance, Considine et al. (2014) explain management reforms in Australia and focus on three policy measures of Working Nation, Job Network and Job Services Australia. They note the introduction of quasi-markets and tights contract management system in the operation of public employment services. Similarly, The US Job Training Partnership Act of 1984 (one of initial practice of competitive tendering in employment services), the UK Employment Zone and Pathways (1994), Work Programme (2011), Hartz Reforms in Germany, marketization practices introduced (2002) in Denmark and in the Netherlands in 2001 are specific examples of the ways that PES have been reformed (Breadahl and Larsen, 2015, Van Berkel, 2014; Hill, 2013; Bredgaard and Larsen, 2007).

Since both governance and the NPM measures change the role of the state in the delivery of public services and particularly employment services it is of significance to highlight the political character of management reforms. Brodkin (2006: 4) suggests that management strategies are fundamentally political since they restructure the operation which in turn has implications for "distribution and the content of social welfare policy". Management reforms change the respective role of public and private sectors in the delivery of employment services given the withdrawal of public agencies from service delivery and a contractual relationship is established between public organizations as purchasers of services and private actors as providers (Considine et al., 2018: 1189). These changing roles entail new regulatory relationships between the state and market as public actors are required to exert more control to assure both quality of services and cost effectiveness (Gilbert, Yeh and Lin, 2018: 439). As public welfare and employment agencies have getting away from the policy goals of full employment and redistributive measures and being more engaged with measures to support employability, competitiveness, flexibility in labour markets a new kind of regulation as steering has emerged (Klinj, 2012: 4; Kirkpatrick et al., 2011: 371; Nunn, 2010: 3; Bredgaard and Larsen, 2007: 291). Regarding new regulatory role of the state Klinj (2012) states why strict regulation is necessary to monitor and control new contractual relationships through enabling and steering roles of the state with respect to performance management and contracting out measures. Indeed, extensive use of contractualism does not lead to less regulation but a different kind of regulation, that is, a new kind of regulation through which the role of public employees changes from complying with rules and procedures to organizing activities and choice through prices and performance related pay. This is what is called in public administration a move from processes and activities (input) towards results and effects (output and outcome) (Bredgaard and Larsen, 2007:291). 
As noted, the NPM reforms are related to governance practices. In ALMPs, bureaucratic way of service provision can be replaced by three modes of governance of hierarchical, marketized and capability friendly through which subordinate and local level of actors assume more roles but with increasing public monitoring (Bonvin, 2008: 371). Bonvin (2008) characterizes the NPM instruments as example of hierarchical one which local actors are held responsible to carry out goals and processes determined by central administration within the framework of "management by objectives". Private agencies may also be subject to such central government control. He situates competition, quasi markets and contracting out practices in ALMPs within the framework of market governance in which the state has no role in service delivery. In Newman's (2007:36) categorization four modes of governance are identified, that is, hierarchical, managerial, network and selfgovernance. While bureaucratic, rule-based traditional structure is taken as a specific feature of hierarchical governance marketization and the use of incentives and goals become distinctive instruments of managerial governance. The other two modes involve civil society organizations, public-private partnership, community groups and welfare users as the realms of less state control and more of collaboration between agencies, organizations.

The paradigm shift from passive to active welfare understanding has given way to new forms of administration or what is called new governance which is basically shaped by new public management thinking and market like mechanisms. Specific processes and implications of these measures include marketization via contractualism, performance management and management by objectives, individualization, and decentralization. However, these processes should be evaluated as general trends as there are not only specific ALMPs and activation practices but also combinations of governance mechanisms and management strategies, (Heidenreich and Graziano, 2014: 3) and these new ways of managing the activation programmes can also have an impact on the effectiveness of proposed employment policies (Bredgaard and Larsen, 2007: 287).

\section{Marketization, Contractualism and Quasi Markets}

Marketization is about the introduction of market like mechanisms in the delivery and implementation of activation programmes and employment services (Klenk, 2015:35). As stated, the main benefits would be an effective way of management, efficiency, consumer choice and cost effectiveness particularly through competition (Van Berke et al., 2012: 263; Bonvin, 2008: 372). Welfare markets in general and activation markets in particular are not conventional markets, they are mainly quasi markets (Considine et al., 2019; Van Berkel et al., 2012a; Considine et al. 2011; Van Berkel and Borghi, 2008; Bredgaard and Larsen, 2007; Considine and Lewis, 2003). Bredgaard and Larsen (2007: 289) underline that "the principal idea is to create free market for employment services in which (primarily private) 
service providers bid in an open competition by public tendering. This is expected to produce better and cheaper employment services than the former system". They add that the behaviour of those delivering services is controlled through economic incentives and it is through contracts with public agencies that activation markets are regulated. Quasi markets of activation programmes are also market since public provision of employment services is replaced by independent providers within a competitive environment and there is a provider-purchaser split (Van Berke et al., 2012: 275; Bredgaard and Larsen, 2007: 289). However, quasi markets are different with three specific characteristics, that is, providers are necessarily private, forprofit agencies, service users and clients are not directly engaged in purchasing relation but the demand for services is public, and it is the state who is responsible for the financing of services. Several countries including Denmark, the US, Switzerland, Netherlands, Australia, the UK, Germany, and Italy have introduced quasi-markets for employment services in the last two-three decades (Considine and Lewis, 2003: 133).

Contractual relations or steering by contracts is one of the defining practices driven by the NPM understanding and these practices result in the transfer of managerialism from private sector to public institutions. (Ehrler, 2012: 329: Bonvin and Moachon, 2007: 404-405). Bonvin and Moachon 2007: 405) identify specific modes of publicly financed employment service provision. The original regime uses bureaucratic tools and rules in the formulation, implementation and regulation of services. Steering by contracts via performance management instruments and management by objectives model relies on managerial relationships with public sector based on strictly defined objectives, available budget and performance indicators within which the level of discretion available to sub-units and local agencies in PES is controlled through tight regulation. In markets for employment services contractual relationship is established via competitive tendering. Despite arguments favouring these market-like practices the operation of quasi markets and the use of management by objective mechanism in service delivery create specific problems that necessitate extensive public regulation (Bredgaard and Larsen, 2007: 290). The rise in transition costs and the tendency of creaming the most advantaged and qualifies jobseekers and parking of the less qualified and weakest ones are two notable problems associated with quasi markets for employment services. Bonvin and Moachon (2007: 402) also notes the changing balance of roles between public and private sectors and local and central authorities and states that "this coincides with the emergence of contractualisation practices within the field of social policies, in which provision agreements fix precise targets and timetables and leave local actors a significant margin for manoeuvre for their implementation. This implies a new role for the central public state in charge of monitoring local practices instead of the old "command and control" mode of government".

Given these, it is important to note political character of both formal and procedural policy reforms which have important implications for social rights of 
citizens. Indeed, in the process of what is called "double activation" (McGann, 2021), activation policies steer a work-based welfare understanding through which citizens are turned into active jobseekers and subject to continuous process of commodification in order to meet their own welfare needs, and under the conditions of marketization of PES the labour of jobseekers, service users or clients are commodified since the placement of jobseekers or selling of their labour to employers becomes the source of the profit gained by private providers of employment services (McGann, 2021: 28-29).

\section{Performance Management in Employment Services}

Performance management principles are the one of the most important principles of the NPM understanding. The main instruments of a given performance management structure would include management by objectives, quality management, benchmarking, controlling and case management (Nunn and Morgan, 2020; Nunn, 2018; European Commission, 2012; Weishaupt, 2010; Mosle et al., 2001). As pointed out, the NPM understanding is informed by public choice theory developing an incentive-based agency account of public institutions (Considine et al., 2018, 1188) and principal-agent model (Weishaupt, 2010; Mosley et al., 2001) according to which the central level of policy making, usually governments, specify policy goals and then centrally set objectives are operationalized at lower-level agents on the basis of quantifiable measures, targets and indicators. In accordance with a general trend from rule-based administration and regulation to objective-based management, it is argued that, if agents are held accountable within the framework of defined objectives and indicators efficiency gains within the public sector will be enhanced (Weishaupt, 2010: 467). Mosley et al. (2001) state that management by objectives as one of the private management models is a system characterized by "quantified targets" with the purpose of improving performance. They note that this system relies on the setting "operational objectives" and "measurement of outputs and outcomes" on the basis of principles of "principles of target setting", decentralized operationalization and implementation, monitoring of ongoing and final results, and practical conclusions based on final performance assessment (Mosley et al. 2001: 3).

In the last three decades, PES have also been the subject to this process underpinned partly by the agenda created by the EU and OECD. According to report prepared by the European Commission (2012) performance might include input measures covering number of offices, spending on staff and programmes, output measures involving the measure of activities for employment like interviews, vacancy registration, training, counselling or sanctions; process quality measures covering the quality of PES activities such as evaluation of interviews, customer and employee satisfaction survey, intermediate outcome measures including benefit duration, number of transition from welfare benefit dependency 
to work, benefit duration, and final outcome measures developed for efficient labour market measures through employment, unemployment or inactivity rates and productivity. Performance management cannot be evaluated without the concern of quality management which has three aspects labour market review, standardized process assessment and customer satisfaction survey (Weishaupt, 2010: 468). In OECD's reports, the importance of governance structures for labour markets is recognised especially in order to assess the impact of policy measures on outcomes (OECD, 2005: 210-212; Grubb, 2004). OECD Report (2005: 226) notes that "without effective performance management, expensive programmes that have no impact can continue to operate indefinitely. Improvements in labour market outcomes are generally available through more systematic implementation of performance management principles".

That policy influence of international organizations is characterized as "the spread of new policy ideas by epistemic communities" or "fast management transfer" aiming at competitiveness at European Scale (Nunn, 2019: 9). With respect to implementation of performance management practices some mechanisms and instruments include peer review through open method of coordination (OMC), Mutual Learning Programmes for PES covering "peer review, learning exchange, thematic events, a database of labour market practices and dissemination seminars" (Nunn, 2019: 9-10). There are also forums supporting these mechanisms, that is, the Mutual Information System on Employment Policy (MISEP) and the Commission's Heads of Public Employment (HoPES) (Weishaupt, 2010: 464-465). With respect to an efficient performance management system, European Commission gives attention to the significance of local level of autonomy in both implementation and the design of ALMPs within the framework of the NPM approach as the central level of administration determines targets and goals, and the local sub-units structures specify the ways that these goals and targets can be realized (ex. Switzerland, Austria). Besides, with respect to Austria and Swiss experiences, the Commission Report underlines the significance of regular labour market target benchmarking, feedback and financial incentives target-based budgets, achievement bonuses as the other vital conditions for a successful performance management system (European Commission, 2013: 1-5).

There are specific benefits attached to performance management and management by objectives system (European Commission, 2012; Ehrler, 2012; 328; Weishaupt, 2010; Mosley et al., 2001). The shift from traditional, rule-based, bureaucratic structures to performance-based, goal-oriented management system might improve accountability, transparency, efficiency. There might also emerge some potential problems due to the necessity of monitoring given that strict monitoring is necessary to avoid setbacks such as creaming and parking; or to control performance payments. This process might result in growing regulation, recentralization, weakening discretion and flexibility available to local levels and subunits and innovation (Weishaupt, 2010: 468; Mosley et al., 2010). 


\section{Individualization and Decentralization}

One of the important implications of the management reforms in PES is the process of individualisation reflected through a focus on individual responsibilities, contractual relationships, and case management strategies (Van Berkel et al., 2010: 469-470, Van Berkel and Borghi, 2008: 398-399; Bonvin and Moachan, 2007:402404; De Graaf, 2007: 13-15). In the process of transformation of universal, unconditional, citizen welfare rights through active welfare understanding individuals are expected to take more responsibility for their own welfare through paid work and improving their employability (Gilbert, 2018; Van Berkel et al. 2007). The individualization of risks and responsibilities is apparent in many social policy reforms. With respect to individualization trend in welfare reforms Bonvin and Moachon (2007: 403) state the ways that in which welfare is understood not just only in terms of distribution of cash benefits "but on the restoration of the beneficiaries' capacity to act and be economically productive". In marketized services including those provided by PES unemployed citizens or job seekers are transformed into customers and in cases where public services are contracted as three-party contracts, the state as funding agency and purchaser, private sector as provider, and individuals as users are parties to a contract (Gilbert, 2018; Van Berkel et al., 2012b: 279).

Three modes of individualization are identified in activation paradigm (Van Berkel and Borghi, 2008: 398-399; Van Berkel and De Graaf, 2007). The first discourse of individualisation underlines the need for "personalized and tailored made programmes" (Van Berkel and Borghi, 2008: 398) as against standardized, undifferentiated service provision. It is argued that in activation services in which unemployed people and social assistance recipients are subject to top-down, not flexible institutional structures are insensitive to individual differences. Thus, case management practices which can be traced back to 1986 British experience and individual action plans used in all EU member states (Weishaupt, 2010: 469; Van Berkel and Borghi, 2008) are of significance to be empowered, to be adequately helped and to be allowed to flourish independently and autonomously" (Bonvin and Moachin, 2007: 403). Weishaupt (2010) adds that besides empowerment, individual action plans have additional advantages of reducing benefit dependency, promoting transparency in PES services. However, all these depend on the nature, form, and content of action plans. The other discourse of individualisation focuses on individuals as customers and consumers for marketized employment services in quasi markets. However, in activation services purchasing power and freedom of choice available to service users is limited and some countries such Germany and the Netherlands have attempted to overcome this problem through voucher schemes and development of personal budgets through which individuals can choose the provider (Van Berkel and Borghi, 208: 398; Bonvin, 2008: 373). Lastly, the individualisation discourse in activation services might refer to introducing the 
logic of social assistance to employment services that is granting entitlements conditional upon responsible behaviour. This idea is particularly observed in workfare programmes within which unemployed people are subject to paternalist and work-ethic discourse to make sure that they are following expected responsible roles and norms (Van Berkel and Borgi, 2008: 398; Bonvin and Moachon, 2007: 403-404). Different individualization discourses are materialized particularly in case management and individual action plans as a specific relation of "contractualizaiton". However, whether these action plans are prepared to meet specific individual needs and circumstances or these contracts are arranged to impose sanctions and force service users for quick labour market integration is a contested issue (Van Berkel and Borghi, 2008).

There are other general trends associated with the NPM thinking and governance reforms including decentralisation, establishment of one-stop agencies and the declining role of social partnership in the decision formulation and implementation of management reforms. These tendencies can be considered within the framework of network governance defined as "a form of organization in which clients, suppliers and producers are linked as co-producers (Considine and Lewis, 2003: 134). A more participative form of governance would enable more collaborative way of specifying the aims of policies and leave flexibility and opportunity for local agents to act. Bonvin (2008: 372-373) takes this as a capability friendly mode of governance which makes local actors responsible and accountable for respective policies and "encompass active involvement in definition of the most adequate modes of activating people". According to Newman (2007: 369) this mode can be described as self-government relying on "self-regulation and selfmanagement with high autonomy, weak external constraints within which service users, citizen assume subjective position in the definition and implementation of activation programmes". This means a more reflexive understanding of individualization: that is: individuals present in public policy process defining the policy goals and implementation. The same view sees individuals as fully capable determining the way of life that they want to pursue and identify activation services to enable citizens to realize their ways of living (Van Berkel and Borghi, 2008: 398399; Bonvin, 2008: 372-373; Bonvin and Moachon, 2007: 404).

Decentralization has been one of the facets of reform measures in PES in accordance with the assumption that activation programmes should reflect local needs and circumstances (Van Berkel, 2009: 27). Authorizing local actors to implement centrally defined goals and devolving the authority of activation to local authors, municipalities and regional actors can enable these agencies to budget their own schemes and to manage programmes and funding regimes (Ehrler, 2012: 329). Britain, Switzerland, the Netherlands, Denmark, Germany are country cases supporting local level of decision making, budgeting, flexibility and sharing responsibilities with municipalities. However, decentralization can also be accompanied with re-centralization trend to minimize differences and 
fragmentation in service quality and rights between and among different localities, to control budget resources and discretion. Governments may attempt to control and monitor the ways the local autonomy is used (Van berkel, 2009; Van Berkel and Borghi, 2008).

Establishment of what is called one-stop agencies (Van Berkel, 2009: 26) or single gateway (Weishaupt, 2010: 475) has been part of PES reforms via integration of activation and benefit services for enabling service user to have an easy access to services. Job Centre Plus in Britain, for instance, combines income protection and activation programmes for jobseekers and social assistance recipients. The Danish Job Centres, the Dutch Centre for Work are other examples of collaboration between different agencies and as an example of network governance.

The use of discretion is an integral part of the NPM understanding as central level of decision makers determine the goals and objectives and incentives and to leave the local or sub-unit to determine the ways to reach these objectives (Brodkin, 2011: 1254). Nevertheless, the growing effect of the NPM practices, marketization and contractualism have given way to a dramatic reduction in the policy impact of social parties, particularly trade unions (Van Berkel, 2009: 28) especially in Continental welfare systems of Germany and the Netherlands (Breidahl and Larsen, 2015:103; Wolfgang et al., 2014). Further marketization has gone hand in hand with technocratic and depoliticised way of policy making which is closed to involvement of social parties, individual service users, unemployed people, and social assistance recipients in the operation of activation programmes.

In the following parts of this paper, the debates on the procedural reforms will be evaluated within the framework of the Turkish case in order to explain both the ways in which the processes shaping public employment services have also affected PES in Turkey, and what the Turkish experience tells about the procedural reforms in the sphere of public employment services.

\section{Restructuring of Public Employment Services in Turkey}

Turkey can be seen a laggard regarding the development of comprehensive activation programmes and the implementation of ALMPs. Before the establishment of Turkish Employment Agency (İŞKUR) as a restructured public employment organization (PEO) the scope and coverage of ALMPs had been limited with shortages in resources, professional staff, and the lack of flexibility. Besides, employment services were considered of being exclusively a public service, and hence the involvement of both for profit and non-for-profit agencies in job placement, job matching, and brokerage were forbidden by the law except for those job brokerage activities in agricultural sector. Higher education institutions were also allowed to support graduates to find jobs in collaboration with private and public institutions (Selek Öz, 2008: 19). Until the 1990s, the main 
activities of the POS (İş ve İşçi Bulma Kurumu) in Turkey covered job placements, job brokerage, skill development, information gathering, supervision of wage levels to manage social problems within the country and abroad (Cosskun, 2017: 134135). With respect to earlier development of ALMPs in Turkey Çiner (2007) and Coşkun (2017) underline the existence of programmes for training and skills development developed in collaboration with or support of external institutions like ILO, the European Council, and the United Nations (the UN). The POS In Turkey had started initiating more focused training programmes from the 1990s onwards. Skill Development Programme in Tourism Sector (1990), Vocational Training for Migrants (1991-Soydaş Entegrasyon Projesi with the support of United Nations Development Programme-UNDP), Vocational Training for the Employment of Young Girls and Women (1991-with the support of UNICEF), Establishment of Vocational Training Centre for Disabled People (1991- with the support of UNDP), public work programmes (1999-with the support of the World Bank) were among such programmes.

Two externally supported projects which pioneered both the implementation of comprehensive activation programmes and the process of restructuring of PES in Turkey were "the Reorganisation of the Turkish POS" (1990-1993) with the technical and financial assistance of the German POS and "Employment and Training Project" initiated with the financial support of the World Bank (1993-2000). The principal elements of the first project were the training of managers, establishment of Centre for Vocational Training and Counselling, development and implementation of training programmes, counselling, and job placement services. Several personnel participated training courses in Germany to be employed in five pilot provinces (Adana, Ankara, Bursa, İstanbul and İzmir). The key drives of Employment and Training Project was further diversification of employment services and to increase their effectiveness, take necessary measures to assist the employability of the unemployed, unskilled workforce and women in productive works through modernization of training and job placement services, information gathering and to improve the statistical analysis and data gathering about labour markets (Cosskun, 2017: 14, 143-144; Çiner,2007: 276-277).

The attempts to modernize public employment services in Turkey led to the establishment of both ISSKUR through Law No: 4904 and private employment agencies in 2003. The relevant literature underlines the factors, which were highlighted to justify the reform of public employment services in Turkey. Güray (2012: 95) states that earlier debates on ALMPs in Turkey can be traced back to the 1980s, and these debates should be linked to the internationalisation of economy, privatizations, and the policy influence of the European Union (the EU) and the World Bank. She also argues how reforms introducing flexibility in labour markets are accompanied with the extensive use of ALMPs. It is also pointed that in relation to European Employment Strategy (EES), on the basis of both membership process 
to the European Union and Development Plans, ALMPs and other policy reforms in labour markets and the restructuring of public employment agency came into the political agenda in the early 2000s (Çetinkaya, 2011: 42-44; Gön, 2011:69-70). Kumaş (2010: 142-147) and Alper (2003:1) also highlight the interaction of external policy influence and dynamics with internal problems, that is, the impact of economic liberalization, deregulation of labour markets and the inability of the POS to adjust to changing conditions to meet needs (such as the needs of skilled labour force) due to limited resources under traditional and institutional structures. According to this argument shaped by the NPM ideas, under the conditions of rising structural unemployment, the changing sectoral composition of economy, widespread use of flexible forms of employment with their bureaucratic, centralized, hierarchical structures traditional PES were far from adapting to changing circumstances effectively. The existing PES were conceived of lacking efficiency, flexibility, and responsiveness (McGann and Murphy, 2021: 6-7; McGann, 2021: 32; Coletto and Guglielmi, 2018: 330; Graziano and Winkler, 2012: 343; Korkut et. al.,2015: 122-124; Gön, 2011: 67; Borghi and Van Berkel, 2007: 91).

As a result of the restructuring, ISSKUR has become the principal institution for securing and improving employment, coping with unemployment, and administering the unemployment insurance benefits (introduced in 1999) (Firat, 2018: 38; Coşkun, 2017: 149, Korkut et.al., 2015: 125-130) The responsibilities of ISSKUR are listed as the development of national unemployment strategy, collecting and analysing data about labour markets, information gathering, supporting the employability of workforce through training services and counselling, job placement, job brokerage and job matching (Sayın, 2005: 411-412). With ISSKUR, the nature of labour market policies gradually changed from the protection of jobs to activating the workforce. Hence, the scope of ALMPs have expanded. The number of people who have access to training and other employment services have also increased (OECD, 2021: 12). Vocational training courses, On the Job Training Programmes, Public Work Programmes, Training Programmes for Entrepreneurship and Disadvantaged Groups have been the principal activation programmes initiated by ISSKUR (Kasapoğlu and Murat, 2018; Acar and Yabonova, 2017; Aşkın and Aşkın, 2017; Şen, 2016).

There were also official debates on activating social assistance recipients started in 2010 and workfare programmes were officially initiated in 2017 through a decree issued by the Ministry of Family and Social Policy (then The Ministry of Labour and Social Security) and cooperation between ISSKUR and Social Solidarity Fund (one of the local agents implementing social assistance programmes) (ASPB, 2017). The most explicit debates on activation (mainly activating social assistance recipients who can work) can be found in National Employment Strategy (NES) which was drafted in 2012 and introduced in 2016 under the element of 'the establishment of link between social protection and employment'. The strategy has elements which have been designed to increase employment and manage 
unemployment through basically ALMPs and introducing more flexibility in labour markets. Şahin (2014) and Kapar (2012) state that main policy aims, and the policy strategies outlined in NES have been in accordance with EES. According to the Ministry of Family, Labour and Social Services among those 1.840 .000 social assistance recipients who can work 244.531 people have been registered to ISKUR for activation. 14.088 social assistance recipients were employed in long-terminsured jobs, 4.493 people were given training and 20.890 people were given consultancy services since 2017 (AÇSHB, 2018).

Turkey has also used public work schemes since the early 1990s (864 participants, 39 public work schemes) to absorb that workforce unemployed because of privatisation and their scope has been extended after 1999 earthquake (4605 participants, 140 programmes). With the $8^{\text {th }}$ Development Plan in the early 2000s public work programmes have been developed as temporary employment opportunity ( 9 months) to target those who are long-term unemployed, women, disabled elderly, to spread work ethics, and manage welfare dependency. In 2015, the number of public work programmes implemented by ISKUR was 234.941 participants in 9.596 programmes (Aşkın and Aşkın, 2017; Özşahin and Karabulut, 2017; Gün, 2013).

The importance of labour market polices is highlighted especially during crisis periods to manage the consequences of crisis conditions for households and the economy in general (Aldan et.al, 2021:8; Gunderson, 2020). COVID-19 health and economic crisis has had a dramatic impact on the Turkish economy and labour markets. Looking at the main economic indicators, for instance, the level of GDP decreased by 9.9 per cent between April 2020 and June 2020. The increase in GDP was 0.9 per cent, 1.8 per cent and 7.4 respectively in 2019, in 2020 and in the third quarter of 2021 (TÜIK, 2021a). The impact of pandemic on labour markets was reflected in the main indicators. The level of employment decreased from 45.7 per cent to 42.8 per cent between 2019 and 2020. In October 2021, the employment rate was 46.2 per cent. The decline in labour market participation rate was from 53.0 to 49.3 per cent between 2019 and 2020 with a slight rise to 52 per cent in October 2021. The changes in the official rate of unemployment does not clearly reflect the number of job losses as there was a relatively modest decline from 13.7 to 13.2 per cent between 2019 and 2020 and then to 11.2 in October 2021 (TÜIK, 2021b, 2021c, 2021d, 2020). ILO (2021) reports that because of social distancing and confinement measures 2.3 million jobs were destroyed by December 2020 with -49.9 per cent reduction in the work hours in April 2020 (-38.5 and-32.5 respectively for women and men). The crisis has exerted a disproportional and uneven effect across different sectors and groups with higher job losses and work hours losses in hospitality and among women, informally employed and self-employed, younger, and low-skilled workers. Only small section of labour force could perform their work through telework, or from home (only 20 per cent of jobs) (ILO, 2021:13 Aygun et. al., 2021: 4; Aldan et.al, 2021: 8; OECD, 2021: 9, 47). 
Against crisis conditions, the main priorities of the governments have been the compensation of income losses of households and protection of jobs. The social protection measures have been limited to only to those formally covered under the system in some countries though some countries extended the coverage of pandemic income maintenance policies to non-standard workers and workers in working informally (ILO,2020: 3). In most of European countries, the use of measures activating the workforce through sanctions and conditionalities were suspended (McGann, 2020) and ALMPs have been directed for hiring in essential sectors and skills development and other services which would foster employability and job transition in the aftermath of the crisis (ILO, 2021: 3, 14, 16; ILO, 2020). In Turkey, the labour market measures during pandemic have shared similar concerns of income maintenance and protection of jobs, and mainly relied on passive measures. Short term work schemes (with 60 per cent replacement rate) were used and conditions for eligibility to benefit was relaxed (with a decrease in the length of contribution from 600 days to 450 days). The scheme was last extended to 30 July 2021 (OECD, 2021: 20). Another measure for protection of jobs was introduced through the law on unpaid leaves during which workers were paid 1170 Turkish Lira. This programme was valid until 31 July 2021 and during this period firms were banned from firing workers. Those employed informally could not benefit from the same measures. The government also initiated social security normalization support as a social security contribution assistance for employers. Firms which withdrawn short-term work scheme were eligible for application for exemption from contributions for six months. (OECD, 2021: 20, 47). These passive measures have been temporary programmes as emergency interventions and therefore we might expect that the scope of ALMPs will be expanded in the future (Gunderson, 2020, 185).

\section{Decentralization and Marketization in Public Employment Services in Turkey}

İ̧KUUR is made up of General Assembly, Executive Board, General Directorate and Provincial Employment and Vocational Training Boards (PEVTBs) (OECD, 2017:12; ISSKUR, 2021a). The General Assembly is organized as an advisory, tripartite body with the participation 79 members selected from public institutions, trade unions, employer organizations, organizations for craftsmen and merchants. The Executive Board manages Unemployment Insurance Benefits and is granted authority to decide the budget and for the approval of contracts with participants from the representatives of trade unions, employers, merchants, and craftsmen. The PEVTBs are responsible for planning, improving local employment services in provinces, and thus expected to contribute to regional development. The PEVTBs established in 2008 are conceived of being a "stake holder platform" to extend the activities of ISSKUR at provincial level in the spheres of employment, vocational training, and lifelong learning. The PEVTBs have served to be a social dialogue 
and inter-institutional cooperation mechanism to respond to local problems by using local resources and to meet the skill needs of local labour markets. The Boards have authority to specify employment policies, to develop local action plans and supervise implementation (OECD, 2017: 13). The law also stipulated a new status of Employment Experts who would be employed to provide qualified personal employment services (Sayın, 2005: 413-414); IŞKUR, 2021b).

Job and career counselling is one of the most important services of ISSKUR. Although these services started in 1991 the scope and quality has been expanded with the training and then employment of professional job and career counsellors in 2012 and 2013. This has given way to delivery of personalized or individualized services planned according to needs and clients or service users. In IŞKUR reports, this is called profile-based counselling system with specific branches including counselling for jobseekers, employers career counselling, career couching for disabled people and job council leadership. Job councils were established in 2017 to serve the disadvantages groups such as women, former convicts, addicts, or disabled people. There are also regular school and workplace visits by İSKUR personnel. The statistics note an increase in the number of individual interviews with the service users from 811.493 to 5.470 .708 between 2012 to 2019 (ISSKUR, 2019: 63-71). These practices display how public employment services have been individualised for the purpose developing tailored-made policies for jobseekers.

Employment fairs and career days can be seen a specific example of job matching activity. The rise in the number of career days was from 41 to 192 from 2011 to 2019. There has also been growing increase in fairs with fluctuations. There were 10 fairs in 2010 with a rise to 37 in 2012 and decline to 28 in 2018 and to 13 in 2019. The reasons of decline in the number of employment fairs are unknown (İSKUR, 2019).

Since 2003, the physical, technological, and human resource capacity of institutions have also been improved with 125 public employment service offices, 81 local agencies, 3.557 branch offices with 8891 employees in 2019. Annual budget of ISSKUR increased from 2.078.206.287 to 12.433.603.000 Turkish Lira between 2012 and 2019 (WAPES, 2021; ISSKUR, 2019; ISSKUR, 2014).

Gön (2011: 70-72) argues that these policy practices demonstrate the ways in which improvements of the quality of services and client satisfaction have become the main priorities of ISSKUR following the restructuring and adoption of total quality management system. This implies that performance management instruments of quantified targets, input measures (such as the number of offices, staff, programs, and the level of spending) and output measures (such as the number of interviews, job placements, participants to training courses) are also used in the provision of employment services (European Commission, 2012; Mosley et al. 2001: 3).

As noted, the establishment of ISSKUR marked a shift in the policy priorities of public services from protection of jobs to activating labour force through 
various strategies. This is revealed in official documents published by ISSKUR since the mid-2000s. The increase in the scope and types of ALMPs and restructuring of public employment services in accordance with the logic of activation display the ways in which both formal and procedural policy reforms have gone hand in hand. The Third General Assembly Decisions (2005) offered an employment strategy and labour market reform strategies with an emphasis on sustaining flexicurity, improvement human capital development and skills development, managing informality, supporting entrepreneurship, assisting disadvantages groups and lifelong learning. (ISSKUR, 2005). A similar policy orientation shapes the $10^{\text {th }}$ General Assembly Decisions (2019) with a due focus on training of younger labour force, improvement of work and job counselling, assistance to disadvantage groups, strengthening the link between the social assistance and employment, and the modernisation of public employment services through social dialogue mechanism and collaboration with private or non-state actors (ISSKUR, 2019).

Official reports of ISSKUR note a clear rise in the intensity of ALPMs and training courses, job placements and counselling services. The number of people who benefited by job placement services especially after 2009 rose from 105.265 to 205.231 between 2009 and 2010. The increase from 791.542 to 1.264 .294 between 2017 to 2021. (İSKKUR 2011; İŞKUR, 2012; İŞKUR, 2014; İŞKUR, 2019). The number of training courses was 28.618 with 277.029 participants. The number of programs rose to 50.333 with 291.298 participants in 2015 , to 92.716 with 381.765 participants in 2017, and to 92.322 with 427.134 participants in 2019 (iŞKUR,2012; İSSUR, 2014; İSKUR, 2017; İSKUR, 2019). Specific activation projects targeting women and younger people in 2006, 2009, 2010 and 2011 were also introduced with the support of the EU (Güray, 2012: 96). The World Bank report also admits (World Bank, 2013, xii) the improvements both in targeting in training courses and the use of instrument to motivate active job search.

The expanding scope of activation has also been accompanied with two other trends which have shaped the nature of PES reforms, that is, marketization and decentralization. The involvement of private employment agencies as forprofit actors in job placement, job brokerage and job matching activities is a clear display of the privatization of employment services in Turkey. Public employment services, however, has been subject to the process of marketization. Given that training services are outsourced to private agencies quasi-markets have come to play growing roles in the ways that ALMPs are carried out. Because voluntary organizations also provide training courses there is a mix economy of employment services within which for profit, non-for profit and public agencies play roles. In addition to training courses provided by ISSKUR, private agencies are also paid in return for the delivery of many training courses through sub-contracting (World Bank, 2013: xii, 36). The World Bank report argues that the courses delivered by private providers have higher returns than those of ISSKUR (World Bank, 2012: 36). Besides commercial sector, non-for-profit sector has also been active in the 
provision free training courses provided through, for instance, collaboration among chambers, employer groups and non-governmental organizations. There have also been public-private cooperation and social responsibility initiatives taken by big business groups such as Koç Group and Elginkan Group (OECD, 2017:16).

The formation of PEVTBs was considered of being a significant step in enhancing the effectiveness of employment services at local level. The Boards are granted authority to plan and settle training programmes with resources provided by ISSKUR. The Directorate in the Boards are involved in the selection of those who applied for training courses (especially in the On-the-Job Training Programmes) (Güray, 2012, 100). This is an example of "managerial or administrative decentralization" (The European Commission, 2011) within which the Boards have flexibility in the use of budget, planning of actions and strategic goals, in determining the groups targeted, in the service delivery, in the use of personnel and outsourcing (OECD, 2017: 13; The European Commission, 2012). Besides the Boards, Provincial Courses through Skills 10 Project (initiated by public-private cooperation among ISSKUR, Turkish Union of Chambers and Exchanges (TOBB), Ministry of Education and the Ministry of Labour and Social Security) are founded to serve the skill demands of employers. And the Boards use the authority to settle the type of training courses together with the local councils which collect information about the demand for labour. As part of the process of decentralization, there are also ISSKUR Service Points in municipalities (OECD, 2017: 17-18). ISSKUR Service Points was established in 2010 with the aim of assisting jobseekers through protocols with local actors, foundations and in 2018 there were 64 points established in municipalities, chambers, career offices of universities and local governments, organized industrial zones (Haberler.com, 2018).

These reforms demonstrate a policy shift from a hierarchical governance to a limited degree of market governance with the creation of quasi-markets of vocational training services and to a network governance emerged with the growing partnership with non-state actors in private sector, non-profit organizations, chambers of trade and industry and other local actors. The involvement of trade unions and employer organizations, chambers, and some other civil society organizations in the governance structure of ISSKUR can also be an example of network governance though the nature and the degree of their policy impact need further elaboration.

The discursive framework used to justify the reform of PES in Turkey is like those in other country examples mentioned in this paper, yet the transformation of public employment services from a centralized structure to more decentralized occurred within a piece-meal reform process occurred through the involvement of external institutions such as the World Bank, the ILO, the EU. Various forms of support provided for specific projects by these organizations can be assessed as the 
case of policy transfer of reforms worked elsewhere (Çiner,2007: 263-264). Given this, it can be suggested that the NPM understanding shapes the nature of PES reforms in Turkey. Nevertheless, the extent to which performance management instruments are used in the evaluation of both ISSKUR services and training courses services provided by profit actors should be further elaborated. Similarly, there is lack of data about the incentive mechanisms or sanctions in the payment system (cost-based, performance-based or outcome based) stated in contracts with private actors. Dur (2017: 104), for instance, argues that there are no incentive mechanisms system to measure the performance of PEAs and underlines the lack of performance-based and target-based monitoring.

Outsourcing and tendering within a competitive structure might give ways to problems like decrease in quality of services or standardization of service provision since private providers act in accordance with payment model with a concern to reduce their costs and maximize their income (McGann, 2021: 34). In Turkey, the employment services outsourced to private providers is limited to training courses and existing providers cannot be involved in job placement services. Even though the scope of marketization seems to be limited such problems might emerge in the Turkish case especially if the scope of quasi markets of employment services are expanded. Marketization, the formation of quasimarkets for training services and decentralization necessitates regulatory interventions to manage the activities of for-profit and local agencies. However, these interventions might undermine flexibility and lead to standardization (McGann, 2021; 34).

There is need for further studies analysing the effectiveness of services provided by ISSKUR especially after procedural reforms. The existing studies raise some issues for policy makers. For instance, in their analysis of the effectiveness of job matching services offered by ISSKUR, Şahin et al. (2019: 174) concludes that despite the growing support provided by ISSKUR, specific groups including highly educated with higher education diplomas and those under 25 years old have benefited relatively less from the programmes. Similarly, Güray (2012: 100-105) argues that the policy impact of vocational training with respect to the employment of women is less effective. The World Bank Report (2013: 25-29) also underlines just a modest impact of vocational training delivered by ISSKUR and argues that the quality of training run by private providers is higher with a lower costs per participant. This outcome is explained with respect to the existence of competition and incentives which are assumed to influence the performance of providers.

Another issue is related to the consequences of the process of decentralization strategy. Administrative decentralization via the transfer of authority to local actors, that is, the Boards, should go hand in hand with ensuring accountability of local actors and transparency in policy decisions, implementation, and outcomes. Güray (2012: 100) notes, for instance, the role of the Boards in the selection of participants of training courses. This authority should be used within 
the framework of clearly defined rules in the selection process to avoid arbitrary practices and equity problems (The European Commission, 2011: ii). The questions of accountability and transparency should also be considered in the private delivery of employment services and vocational training services. Ensuring that private providers follow quality standards, avoid creaming and parking problems are regulatory challenges that public authorities must cope with and take necessary measures in the service contracts with for private service providers (Holden, 2012: 219).

\section{Conclusion}

Different forms of activation programmes as a distinct field of welfare state restructuring and regulatory strategy have been developed and continuously reformulated to respond to various regulatory policy goals of cost-containment, reducing benefit dependency, decollectivitization of social assistance, rapid labour market integration, activating unemployed and poor households or enhancing flexibility in labour market (Peck, 2002: 352-356). Since the 1980s, public sector administration has been restructured through management reforms shaped by the NPM instruments of market-based tools of performance management system, contractualism and competitive tendering. PES and activation programmes have been subject to similar practices to make both citizens and welfare states more active and less passive. Establishment of quasi-markets in public employment services, the use of performance-based tools of management by objectives, quality management have constituted the principal pillars of management reforms though scope of such measure has changed. The lack of choice for service users, the need both to contain costs and increase the quality of services through for instance competitive tendering have constituted the discursive framework of these programmes (Bredgaard and Larsen, 2007: 298).

Since the 1990s, social protection system and labour markets in Turkey have been subject to reforms which have accelerated the marketization and privatization of welfare services and benefits. A residualised social protection system has been accompanied with recommodification of labour through "activation turn" (McGann, Murphy, 2021: 1). The existing studies show the ways in which activation policies through ALMPs in Turkey have been triggered by the interaction of the external policy influence of international institutions with the liberalization of economy and the changing dynamics of labour markets starting with the 1980s. Although Turkey is a late comer in activation reforms the pace of reforms has been accelerated in the last two decades.

In the reform process of public employment services, there is an evident move from a centrally organized, hierarchical public structure with a focus on job protection to a fragmented system within a mixed economy of employment services delivered by both public and private agencies or through public-private 
partnership. Decentralization, marketization via the quasi-markets of training services and individualization have been the main pillars of procedural reforms. Understanding the extent to which the NPM ideas shape the reform of public employment services requires further elaboration, but the existing discourses used to justify the reforms are informed by the NPM approach (McGann, 2021).

In PES reforms in Turkey and elsewhere, the changing role of the state during reform process is also of importance. Active welfare state, contracting state, enabling state (Gilbert, 2016) are concepts used describe the ways in which the state has assumed the role of steering through new regulatory mechanisms to monitor the practices of local, sub-unit agencies instead of strict command/control way of administration (Bonvin and Moachan, 2007: 402). Given the influence of managerialism in the public administration Penz et.al (2017: 543) state how the state actors have become "public faces" of neoliberalism and acted to govern the service users through new tools and modes of the NPM understanding. 


\section{REFERENCES}

Acar, O.K., Yabonava, E.K. (2017) 'Aktif İşgücü Piyasası Politikaları Çerçevesinde Kütahya İşkur'un Mesleki Eğitim Faaliyetleri, Mehmet Akif Ersoy Üniversitesi Sosyal Bilimler Enstitüsü Dergisi, 4 (2), 85-111.

Aile, Çalışma ve Sosyal Hizmetler Bakanlığı (AÇSHB) (2018) 2018 Yılı Faaliyet Raporu.

Aldan, A., Çirakli, M.E, Torun, H. (2021) "Covid 19 and the Turkish labour market: Heterogenous effects across demographic groups, Central Bank Review, $\mathrm{xxx}, 1-9$.

Alper, Y. (2003) “İş ve İşçi Bulma Kurumu'ndan Türkiye İş Kurumu'na”, İş, Güç Endüstri İlişkileri ve İnsan Kaynakları Dergisi, 5(2), 1-5.

Aşkın, U., Aşkın, E.Ö (2017) 'Aktif İstihdam Politikası Olarak Toplum Yararına Programlar', Gazi İktisat ve İşletme Dergisi, 3 (3), 1-16.

Aygun, A.H, Koksal, S., Uysal, G. (2021) "The Effects of Covid-19 on Labour Market Outcomes in Turkey", ERF Policy Brief No: 72, 1-6.

Bonvin, J.M. (2008) "Activation Policies, New Modes of Governance and the Issue of Responsibility", Social Policy and Society, 7(3), 367-377.

Bonvin, J. M, Moachon,E. (2007) "The Impact of Contractualism in Social Policies", International Journal of Sociology and Social Policy, 27 (9/10), 401-412.

Borghi, V., Van Berkel, R. (2007) 'New Modes of Governance in Italy and the Netherlands: the Case of Activation Policies, Public Administration, 85 (1), 83-101.

Bredgaard, T., Larsen, F. (2007) "Implementing Public Employment Policy: What Happens When Non-Public Agencies Take Over?", International Journal of Sociology and Social Policy, 27 (7/8), 287-300.

Breidahl, K. N, Larsen, F. (2015) “The Developing Trajectory of The Marketization of Public Employment Services in Denmark-A New Way Forward or the End of Marketization", European Policy Analysis, 1(1), 92-107.

Brodkin, E. Z. (2011) "Public Work: Street-Level Organizations under New Managerialism”, Journal of Public Administration, 21, 253-277.

Brodkin, E. Z. (2006) "Bureaucracy Redux: Management Reformism and the Welfare State, Public Management Research Association, 17 (1), 1-17.

Coletto, D., Guglielmi, S. (2018) "Activation policies in action: Unemployed people and public officers in face of the economic crisis", International Journal of Sociology and Social Policy, 38 (3-4), 329-344.

Considine, M., O'Sullivan, S., Mcgann, M., Nguyen, P. (2019) 'Locked-in or Lockedout: Can a Public Services Market Really Change", Journal of Social Policy, https://doi.org/10.1017/S0047279419000941, 1-22.

Considine, M., Nguyen, P., O'Sillivan, S. (2018) "New Public Management and the Rule of Economic Incentives: Australian Welfare-to Work from Job Market Signalling Perspective”, Public Management Review, 20 (8), 1186-1204. 
Considine, M., O’Sullivan, S., Nguyen, P. (2014) “New Public Management and Welfare-to-Work in Australia: Comparing the Reform Agendas of the ALP and the Coalition", Australian Journal of Political Science, 49 (3), 469-485.

Considine, M., Lewis, J. M., O’Sullivan S. (2011) “Quasi-Markets and Service Delivery Flexibility Following a Decade of Employment Assistance Reform in Australia", Journal of Social Policy, 40 (4), 811-833.

Considine, M.,Lewis, M.L (2003) "Bureaucracy, Network, or Enterprise? Comparing Models of Governance in Australia, Britain, the Netherlands, and New Zealand", American Society for Public Administration, 63 (2), 131-140.

Coşkun, B. (2017) "Türkiye İş ve İşçi Bulma Kurumunun Yeniden Yapallanma Süreci", Turkish Journal of Marketing, 2 (3), 125-155.

Çetinkaya, E. (2011) "Türkiye İş Kurumu ve Hizmetlerinin Dönüşümü Konusunda Sosyal Tarafların Görüşleri, Sosyal Siyaset Konferansları, 61 (2): 39-41.

Çiner, U. (2007) 'Türkiye'de Çalışma YönetimininDönüşümü: İstihdamın Yönetimindeki Dönüşüm, Ataman, B.A. (ed.) in Prof. Dr. Cahit Talas

Anısına Güncel Sosyal Politika Tartışmaları, Ankara: Ankara Üniversitesi Siyasal Bilgiler Fakültesi Yayınları, 259-284

Deeming, C., Smyth, P. (2015) "Social Investment after Neoliberalism: Policy Paradigms and Political Platforms", Journal of Social Policy, 44 (2), 297-318

Dostal, J. M. (2008) "The workfare Illusion: Re-examining the Concept and the British Case", Social Policy and Administration, 42 (1), 19-42.

Dur, V. (2017) "Marketization in Public Employment Services: Lessons from UK Experience for Turkey" Sosyal Güvence, 12 (6), 89-104.

Ehrler, F. (2012) "New Public Governance and Activation", International Journal of Sociology and Social Policy, 32 (5/6), 327-339.

European Commission (2013) "Performance Management in Public Employment Services: Benchmarking, Clustering and Individual Performance Management", Follow up to Peer Review: Performance Management in PES, Copenhagen.

European Commission (2012) Performance Management in Public Employment Services, Analytical Paper, 1-49.

European Commission (2011) Decentralization of Public Employment Services, Analytical Paper, i-29.

Fırat, Z. (2018) “İstihdam Politiklarının Oluşturulmasında İşkur'un Etkinliği ve Özel İstihdam Kurumları", Paradoks Ekonomi, Sosyoloji ve Politika Dergisi, 14 (1), 31-44.

Grover, C., Stewart, J. (1999) "Market workfare: Social Security, Social Regulation and Competitiveness in the 1990s", Journal of Social Policy, 28 (1), 73-96.

Gön, E. (2011) "Kamu Kurumlarında Yeniden Yapılanmanın Müşteri Memnuniyetine Etkileri”, Bingöl Üniversitesi Sosyal Bilimler Enstitüsü Dergisi, 1 (1), 57-78. 
Gün, S. (2013) ‘Toplum Yararına Çalışma Programı: İşsizlikle Mücadelede Yeni Bir Yöntem mi?’, Sosyal Güvenlik Dergisi, 3(2), 76-95.

Graziano, P.R., Winkler, J. (2012) "Governance and implementation of activation policies: Czech Republic and Italy compared", International Journal of Sociology and Social Policy, 32 (5-6), 340-352.

Grubb, D. (2004) "Principles for the Performance Management of Public Employment Services, Public Finance and Management, 4(3), 352-398.

Güray, M. (2012) "A Case Study for Evaluation of Trainings under Active Labour Market Policies in Turkey for Women Empowerment", Çalışma İlişkileri Dergisi, 3 (2), 90-108.

Haberler.Com (2018) İşkur'dan Vatandaşa Hizmet Noktaları. https://www.haberler.com/iskur-dan-vatandasa-hizmet-noktalari-11279403haberi/. (19.12.2021).

Heidenreich, M., Graziano, P.R. (2014) "Lost in Activation? The Governance of Activation Policies in Europe", International Journal of Social Welfare, $23,1-5$.

Hill, G. (2013) "The Marketization of Employment Services and the British Work Programme", Competition and Change, 17 (2), 197-207.

Holden, C. (2012) "Commercial Welfare", Alcock, P., May, M. and Wright, S. (eds.) in Student's Companion to Social Policy, West Sussex: Wiley and Blackwell, 215-220.

ILO (2021), Impact of the Second Wave COVID Measure on Employment in Turkey, Research Brief, 1-15.

ILO (2020) "Covid-19: Public employment services and labour market policy responses", Policy Brief, 1-25.

İSKUUR (2021a) Organization. https://www.iskur.gov.tr/en/corporate/organization/. (18.12.202)

IŞKUR (2021b) History. https://www.iskur.gov.tr/en/corporate/history/Accessed (18.12.2021).

İSKUR (2017) Türkiye İş Kurumu 9. Genel Kurul Çalsşma Raporu https://media.iskur.gov.tr/13592/9-genel kurul raporu.pdf. (18.12.2021)

İsKKUR (2019) Türkiye İş Kurumu 10. Genel Kurul Çalışma Raporu. https://media.iskur.gov.tr/33490/10-genel-kurul-raporu.pdf. (18.12.2021)

İSSKUR (2014) Türkiye İş Kurumu VI Genel Kurul Çalışma Raporu. https://media.iskur.gov.tr/13590/8-genel-kurul-raporu.pdf. (18.12.2021).

İSKKUR (2012) Türkiye İş Kurumu 7. Genel Kurul Çalışma Raporu. https://media.iskur.gov.tr/13588/7-genel-kurul-raporu.pdf. (18.12.2021).

İŞKUR (2011), Türkiye İş Kurumu VI Genel Kurul Çalışma Raporu. https://media.iskur.gov.tr/13586/6-genel-kurul-raporu.pdf. (18.12.2021).

İŞKUR (2005) 3. Genel Kurul Kararları: Ulusal İstihdam Politikaları ve İşsizlik Sorununa Çözüm Önerileri. https://media.iskur.gov.tr/13586/6-genel-kurulraporu.pdf (18.12.2021). 
Jenson, J. (2015) "Broadening the Frame: Inclusive Growth and the Social Investment Perspective", McBride, S. Mahon, R. and G. W.Boychuk (eds.), in After'08: Social Policy and the Global Financial Crisis, Vancouver: UBC Press, 40-58.

Kalvane, I. (2015) "Business Model Choice for Latvian Public Employment Service: What is the Best for Labour Force Competitiveness", 20 th International Scientific Conference Economics and Management, Latvia.

Kapar, R. (2012) 'Ulusal İstihdam Stratejisi Taslşağında İstihdam-Sosyal Koruma İlişkisi, Ulusal İstihdam Stratejisi Sempozyumu (ed.), İstanbul: Türk-İş, 64-87.

Kasapoğlu, M., Murat, S (2018) 'Aktif İstihdam Politikalanı ve Türkiye'de İşkur tarafindan uygulanan Aktif İstihdam Politikalarına Güncel Bir Bakış', Mehmet Akif Ersoy Üniversitesi Sosyal Bilimler Enstitüsü Dergisi, 20 (25), 485-502

Kirkpatrick, I., De Ruyter, A., Hoque, K., Lonsdale, C. (2011) 'Practising What They Preach? The Disconnect Between the State as Regulator and the User of Employment Agencies", The International Journal of Human Resource Management, 22 (18), 3711-3726.

Klenk, T (2015) "The Governance of welfare markets-trends and challenges: Introduction to the special issue", European Policy Analysis, 1(1), 35-40.

Klijn, E. H (2012) Public Management and Governance: A Comparison of Two Paradigms to Deal with Modern Complex Problems, Faur, D.L (ed.) in The Handbook of Governance, Oxford: Oxford University Press, 201-214.

Knotz, C. M. (2018) "A rising workfare state? Unemployment benefit conditionality in 21 OECD countries, 1980-2012., Journal of International and Comparative Social Policy, 34 (2), 91-108.

Korkut, G., Acar, O.K, Tetik, A. (2015) "Yeni Kamu Yönetimi Anlayışı ile Değisşen Kamu Hizmeti ve Türkiye İş Kurumu”, İş ve Hayat, 1(2), 107-135.

Kumaş, H. (2010) "Türkiye İş Kurumu Faaliyetleri ve İsgücü Piyasası İhtiyaçları Arasındaki Uyum", Sosyoekonomi, 1, 131-165.

McGann, M. (2020) "The political economy of welfare in a time of coronavirus: post-productivism as a state of exception", Irish Journal of Sociology, 28 (2), 225-230.

McGann, M., Murphy, M.P. (2021) "Introduction: The Dual tracks of welfare and activation reform-Governance and conditionality, Administration, 69 (2), 1-6.

McGann, M. (2021) "Double Activation: Workfare meets marketization", Administration, 69 (2), 19-42.

Mosley, H., Schütz, H., Breyer, N. (2001) "Management by Objectives in European Public Employment Services", Discussion Paper, Berlin.

Newman, J. (2007) “The Double Dynamics of Activation”, International Journal of Sociology and Social Policy”, 27 (9/10), 364-375. 
Nunn, A., Morgan, J. (2020) "The Political Economy of Public Employment Services: Measurement and Disempowerment Empowerment", Policy Studies, 41 (1), 42-62.

Nunn, A. (2019) "Neoliberalization, Fast Policy Transfer and The Management of Labour Market Services", Review of International Political Economy, https://doi.org/10.1080/09692290.2019.1625424, 1-21.

Nunn, A. (2018) "Do Employment Services Need to Be Neoliberal", Hooley, T., Sultana, R. Thomsen, R. (eds.) in Career Guidance for Emancipation, New York: Routledge, 166-182.

Nunn, A. (2010) "Performance management and neo-liberal labour market governance: the case of the UK", Sun, W. Stewart, J., Pollard, D. (eds.) in Reframing Corporate Social Responsibility: Lessons from the Global Financial Crisis, Bingley: Emerald Group Publishing Limited, Bingley,77-99.

OECD (2021), OECD Economic Surveys: Turkey. Overview, 1-78.

OECD (2017) OECD Reviews on Local Job Creation: Employment and Skills Strategies in Turkey.

OECD (2005) "Public Employment Services: Managing Performance", OECD Employment Look.

Özşahin, L. and Karabulut, K. (2017) 'Post-Keynesyen İktisatta Toplum Yararına Çalışma Programlarının Analizi, Kafkas Üniversitesi İİBF Dergisi, 8(16), 319-352.

Peck, J. (2002) "Political Economies of Scale: Fast Policy, Interscalar Relations, and Neoliberal Workfare", Economic Geography, 78 (3), 331-360.

Penz, O., Sauer, B., Gaitsch, M., Hofbauer,J., Glinser, B. (2017) "Post-burecratic encounters: Affective Labour in Public Employment Services, Critical Social Policy, 37 (4), 540561.

Pollitt, C. (2001) "Clarifying Convergence. Striking Similarities and Durable Differences in Public Management Reform", Public Management Reform, 4 (1), 471-492.

Sayın, A.K. (2005) "Istihdam Hizmetlerinin Yeniden Yapılandırılması Sürecinde Türkiye İş Kurumu”, Soyal Siyaset Konferansları Dergisi, 0 (49): 405-423.

Selek Öz, C. (2008) “4857 Sayılı İş Kannu Döneminde İş ve İşçi Bulmaya Aracılık Faaliyetleri, TÜHİS İş Hukuku ve İktisat Dergisi, 21 (5-6): 18-30.

Soantken, M., Weishaupt, J. T. (2015) "When Social Parties Unite-Explaining Continuity and Change in Austrian and Dutch Labour Market Governance", Social Policy and Administration, 49 (5), 59

Sol, E. (2010) "Vouchers, NPM and The Provision of Public Employment Services", European Journal of Social Security, 12(4): 343-356.

Şahin, M., Nal, M., Kaya, F. (2019) “Aktif İşü̈cü Politikları İşsizliği Nasıl Etkiliyor? İşkur Eşleştirme Hizmeti Etki Analizi”, Sosyal Güvenlik Dergisi, 9(1), 161176. 
Şahin, C..E. (2014) 'Ulusal Istihdam Stratejisinin Dayanağ1 olarak Avrupa İstihdam Stratejisinin Analizi ve Türkiye Emek Piyasalarının Dönüşümü, Müftüoğlu, Ö., Koşar, A. (eds.) in Türkiye'de Esnek Çalışma, İstanbul: Doğa Basın Yayin, 43-67.

Şen, M. (2016) 'Aktif İşgücü Piyasası Politikaları Kapsamında Türkiye'de Mesleki Eğitim Kurslarının Analizi', Uluslararası Ekonomi ve Yenilik Dergisi ,2 (1): 67-89.

Terziev, V. (2020), "Provision of Integrated Employment and Social Assistance Services", Economy and Production Proceeding of the International Science and Technology Conference "FarEastCon-2018" Volume 138, October 2-4, 201, Vladivostok, Russian Federation.

TÜIKK (2021a) Veri Portalı

https://data.tuik.gov.tr/Bulten/Index? $\mathrm{p}=\mathrm{D} \% \mathrm{C} 3 \% \mathrm{~B} 6$ nemsel-Gayrisafi-Yurt$\% \mathrm{C} 4 \% \mathrm{~B} 0 \% \mathrm{C} 3 \% \mathrm{~A} 7 \mathrm{i}-\mathrm{Has} \% \mathrm{C} 4 \% \mathrm{~B} 1 \mathrm{la}-\mathrm{III} .-\mathrm{\%} \% \mathrm{C} 3 \% 87$ evrek:-Temmuz--Eyl\%C3\%BCl,-2021-37183\&dil=1. (19.12.2021).

TÜİK(2021b)VeriPortall.https:/ /data.tuik.gov.tr/Bulten/Index? $\mathrm{p}=\% \mathrm{C} 4 \% \mathrm{~B} 0 \% \mathrm{C} 5 \%$ 9Fg $\% \mathrm{C} 3 \% \mathrm{BCc} \% \mathrm{C} 3 \% \mathrm{BC}-\% \mathrm{C} 4 \% \mathrm{~B} 0$ statistikleri-Ekim- 2021 37491\&dil=1.(19.12.2021).

TÜIK (2021c)https://data.tuik.gov.tr/Bulten/Index?p=Isgucu-Istatistikleri-Ekim2021-37491. (19.12.2021).

TÜIK(2021d)https://data.tuik.gov.tr/Bulten/Index?p=Isgucu-Istatistikleri-2020-

37484. (19.12.2021).

TÜİK(2020)https://data.tuik.gov.tr/Bulten/Index?p=Isgucu-Istatistikleri-201933784. (19.12.2021).

WAPES (2021) Turkish Employment Agency. https://wapes.org/en/node/268. (19.12.2021).

Wolfgang, L.M, Behrend, O., Sondermann, A. (2014) 'Activation, Public Employment Services and their Clients: The Role of Social Class in Continental Welfare State", Social Policy and Administration, 18 (5), 594-612.

Weishaupt, J. T. (2010) "A Silent Revolution? New Management Ideas and the Reinvention of European Employment Services", Socio-Economic Review, 8, 461-486.

Whitworth, A., Carter, E. (2014) "Welfare to Work Reform, Power and Inequality: FOM Governance to Governmentalities", Journal of Contemporary European Studies, 22 (2), 104-117.

World Bank (2013) Turkey: Evaluating the Impact of İskur's Vocational Training Programs, v-46.

Van Berkel, R. (2014), "Quasi-markets and the Delivery of Activation-A Frontline Perspective", Social Policy and Administration, 48 (2), 188-203.

Van Berkel, B., De Graaf, W., Sirovatka, T. (2012a) "Governance of the Activation Policies", International Journal of Sociology and Social Policy, 32 (5/6), 260-272. 
Van Berkel, R., Sager, F., Ehrler, F. (2012b) "The Diversity of Activation Markets in Europe", International Journal of Sociology and Social Policy, 32 (5/6), 273-285.

Van Berkel, R. (2009) "The Provision of Income Protection and Activation Services for the Unemployed in Active Welfare States. An International Comparison", Journal of Social Policy, 39 (1), 17-34

Van Berkel, R., Borghi, V. (2008) "Review Article: The Governance of Activation", Social Policy and Society, 7(3), 393-402.

Yeh, H., Wan, L. (2018) "Disability Employment Services Under New Public Management: A Comparison of Australia and Taiwan, International Social Work, 61 (3), 437-450. 
